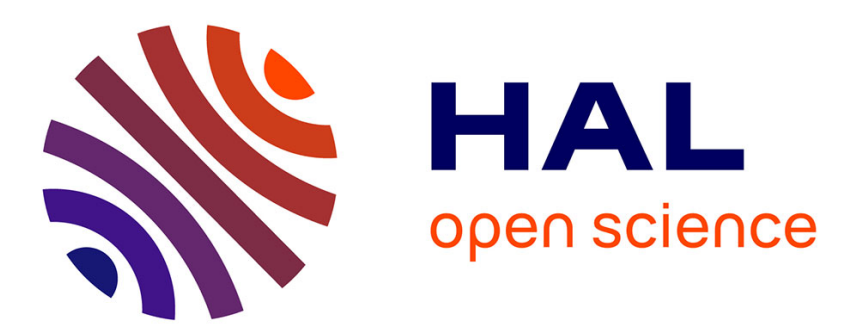

\title{
Environmental quality, public debt and economic development
}

Mouez Fodha, Thomas Seegmuller

\section{To cite this version:}

Mouez Fodha, Thomas Seegmuller. Environmental quality, public debt and economic development. Environmental and Resource Economics, 2014, 57, pp.487-504. 10.1007/s10640-013-9639-x . halshs00555625

\section{HAL Id: halshs-00555625 https://shs.hal.science/halshs-00555625}

Submitted on 14 Jan 2011

HAL is a multi-disciplinary open access archive for the deposit and dissemination of scientific research documents, whether they are published or not. The documents may come from teaching and research institutions in France or abroad, or from public or private research centers.
L'archive ouverte pluridisciplinaire HAL, est destinée au dépôt et à la diffusion de documents scientifiques de niveau recherche, publiés ou non, émanant des établissements d'enseignement et de recherche français ou étrangers, des laboratoires publics ou privés. 


\section{GREQAM}

Groupement de Recherche en Economie Quantitative d'Aix-Marseille - UMR-CNRS 6579

Ecole des Hautes études en Sciences Sociales Universités d'Aix-Marseille II et III
Document de Travail n$^{\circ} 2011-02$

\title{
Environmental quality, public debt and economic development
}

\author{
Mouez Fodha \\ Thomas Seegmuller
}

January 2011 


\title{
Environmental quality, public debt and economic development*
}

\author{
Mouez Fodha ${ }^{\dagger}$ \\ University of Orléans and Paris School of Economics. \\ Centre d'Economie de la Sorbonne \\ Maison des Sciences Economiques, 106-112 Bld de l'Hôpital, \\ 75013 Paris Cedex, France.
}

Tel: (33) 1440782 21. Fax: (33) 144078231.

(fodha@univ-paris1.fr)

Thomas Seegmuller

$C N R S$ and GREQAM.

Centre de la Vieille Charité,

2 rue de la Charité,

13236 Marseille Cedex 02, France.

Tel: (33) 4911407 89. Fax: (33) 491900227.

(thomas.seegmuller@univmed.fr.)

January 2011

${ }^{*}$ This paper benefits from the financial support of French National Research Agency Grant (ANR-09-BLAN-0350-01).

${ }^{\dagger}$ Corresponding author. 


\title{
Environmental quality, public debt and economic development
}

\begin{abstract}
This article analyzes the consequences on capital accumulation and environmental quality of environmental policies financed by public debt. A public sector of pollution abatement is financed by a tax and/or public debt. We show that if the initial capital stock is high enough, the economy monotonically converges to a long-run steady state. On the contrary, when the initial capital stock is low, the economy is relegated to an environmental-poverty trap. We also explore the implications of public policies on the trap and on the long-run stable steady state. In particular, we find that government should decrease debt and increase pollution abatement to promote capital accumulation and environmental quality at the stable long-run steady state.
\end{abstract}

JEL classification: H23, H63, Q56.

Keywords: Environmental policies, pollution abatement, public debt, economic development, poverty trap. 


\section{Introduction}

Environmental protection programs are often constrained by long-term fiscal objectives which impose to control public deficits and public debt evolution. These long-term constraints have significant consequences for developing countries. The search for financing mechanisms that do not increase debt burden has renewed interest in debt-for-nature swaps. ${ }^{1}$ Therefore, debtor countries reduce their debt burden, and free up budgetary resources for environmental spending. In 1991, the Paris Club $^{2}$ introduced a clause that allowed members to convert all official public debt through debt swaps with social or environmental objectives (Jha and Schatan, 2001; Ruiz, 2007). This led to a marked increase in debt-for-nature initiatives. Canada, Finland, France, Sweden, Switzerland and the United States were the first countries to make use of the Paris Club clause in the environmental sphere (see Moye, 2003). Finally, debt swaps were part of the negotiating text for the Copenhagen summit.

The aim of this paper is to analyze the economic consequences of such fiscal instrument. More precisely, we study the environmental policy under a debt stabilization constraint, when public actions to protect the environment are at least partially financed by public funds. Could public debt be a solution ${ }^{3}$ for the

\footnotetext{
${ }^{1}$ In such swaps a non-governmental organisation (NGO) purchases developing country debt on the secondary market at a discount from the face value of the debt title. The NGO redeems the acquired title with the debtor country in exchange for a domestic currency instrument used to finance environmental expenditures (see Hansen, 1989; Jha and Schatan, 2001; Sheikh, 2008). The first agreement was signed between Conservation International and Bolivia in 1987. More recently, such a bilateral deal was signed between the United States and Indonesia, swapping nearly US\$ 30 million of Indonesian government debt owed to the United States over the next eight years against Indonesia's commitment to spend this sum on NGO projects benefiting Sumatra's tropical forests (see Cassimon et al., 2009).

${ }^{2}$ Paris Club is a forum for negotiating debt restructurings between indebted developing countries and official bilateral creditors.

${ }^{3}$ For instance, the Stern Review (2007) estimates that the short-term cost of reducing greenhouse gas emissions could be limited to $1 \%$ of global GDP. This environmental engagement would avoid the economic and social costs of long-term global warming, estimated at (at least) $5 \%$ of global GDP. Could the present generations borrow $1 \%$ of global GDP today in order to finance the fight against the emission of greenhouse gas emissions? If the long-term cost of borrowing is lower than the cost of global warming, then public debt policy could be an efficient solution.
} 
financing of environmental policies? In other words, is it possible and beneficial for all to substitute a financial burden to an environmental burden?

We consider an overlapping generations model à la Diamond (1965) with an environmental intergenerational externality. Indeed, longevity is increasing in environmental quality. We assume that public environment maintenance expenditure could be financed by issuing public debt. Moreover, a debt stabilizing constraint imposes a constant level of debt per capita.

By using this framework, we show that if the initial capital stock is high enough, the economy monotonically converges to a long-run steady state. On the contrary, when the initial capital stock is too low, the economy is relegated to an environmental-poverty trap. In opposition to many papers (John and Pecchenino, 1994; John et al., 1995; Mariani et al., 2010), we find that the economy may be characterized by a conflict between environmental quality and capital accumulation. Increasing debt and/or public spending reduces the capital stock at the long-run stable steady state, but improves environmental quality. Finally, we show that when the government decreases debt and increases environmental protection spending (the debt-for-nature swaps solution), it may improve capital accumulation and environmental quality at the long-run steady state, toward which the economy converges if the initial conditions are not too low. Moreover, such a policy is welfare improving.

Previous papers have analyzed the consequences of environmental policies on environmental quality, growth and welfare (Howarth and Norgaard, 1992; John and Pecchenino, 1994; John et al., 1995; Jouvet et al., 2000). Nevertheless, in all these studies, government cannot fund pollution abatement programs by issuing public debt. However, debt financing has already been introduced in dynamic models with environmental concerns (Bovenberg and Heijdra 1998; Heijdra et al. 2006), but these contributions focus on a different issue than ours. Instead of using debt to finance a share of pollution abatement, debt policy makes possible 


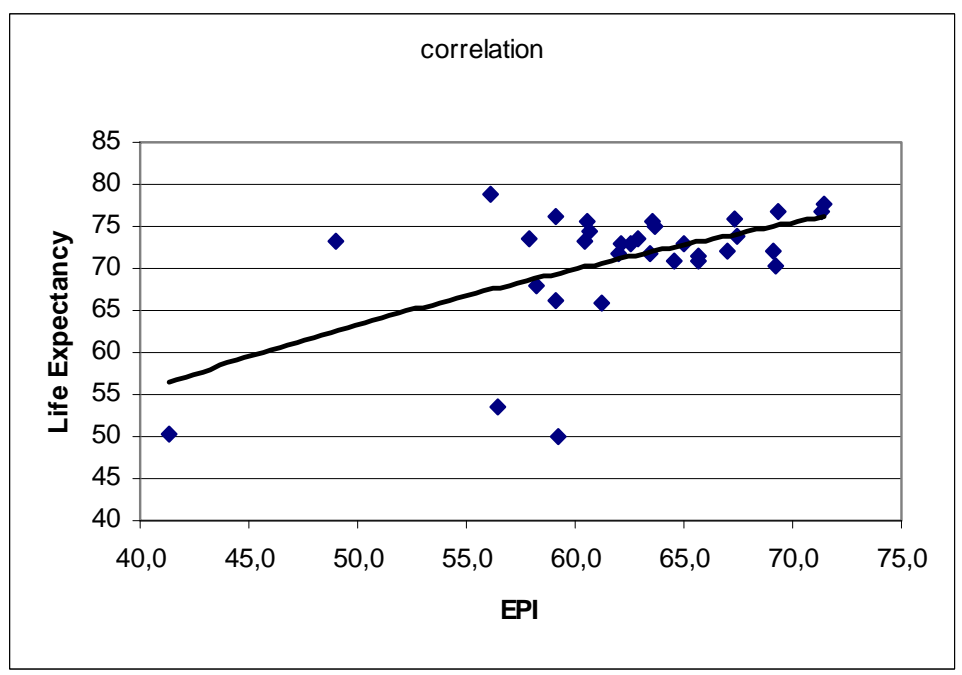

Figure 1: Life expectancy and environmental quality (2004).

to redistribute welfare gains from future to existing generations. In our model, the role of the public debt is twofold: as usual, it redistributes welfare among existing and future generations, but first of all, it finances the public pollution abatement sector. ${ }^{4}$ Hence, the redistribution properties of the public debt are limited by the environmental engagement of the government.

Finally, in our paper, we also take into account the impact of environmental quality on health and life expectancy (see for instance, Figure ${ }^{5} 1$ ). This assumption is justified by the results of an increasing number of empirical studies measuring the health effects of pollution (OECD, 2008). These relationships are nowadays well-documented and are probably the most striking features of

\footnotetext{
${ }^{4}$ This is also the case in a companion paper, Fodha and Seegmuller (2010). However, in this contribution, there is also private abatement and the results mainly depend on the efficiencies of private versus public abatement.

${ }^{5}$ Figures 1, 3 and 4, represent a cross-section of 32 developing countries, which have some similar macroeconomic characteristics. Namely, we have selected Albania, Algeria, Azerbaijan, Botswana, Brazil, Bulgaria, China, Ecuador, Egypt, Salvador, Gabon, Jordan, Lebanon, Macedonia, Malaysia, Mexico, Morocco, Namibia, Panama, Paraguay, Peru, Philippines, Romania, Russia, Sri Lanka, Syria, Thailand, Tunisia, Turkey, Ukraine, Uruguay, Venezuela. Environmental quality is approximated by the Environmental Performance Index EPI. Sources: World Bank (2010) for economic data and YCELP (2010) for environmental data.
} 
the negative impact of pollution on individuals. Recently, Kampa and Castanas (2008) and Neuberg et al. (2007) confirm that exposures to air pollutants are linked to reduced life expectancy. The relation between longevity and the environment is studied by Pautrel (2008), Jouvet et al. (2010), Mariani et al. (2010) and Varvarigos (2010). In these articles, the economy faces a trade-off between financing education and health programs or environmental protection programs. But, once again, they do not consider the possibility for governments to fight environmental degradation by issuing public debt.

In the next section, we present the model. The intertemporal equilibrium is defined in Section 3. The fourth section looks at the steady-states, while Section 5 is devoted to dynamics analysis. Finally, Section 6 presents the comparative statics. The last section concludes. Technical details are relegated to the Appendix.

\section{The Model}

We consider an overlapping generations model with discrete time, $t=0,1, \ldots,+\infty$, and three types of agents: consumers, firms and a government.

\subsection{Consumers}

Consumers live for two periods. The size of the generation born at period $t$ is $N_{t}$. Each person will have $n \geqslant 1$ children during his youth. Hence, the generation born at the next period will have a size $N_{t+1}=n N_{t}$. When old, each one has a longevity $\beta\left(e_{t}\right) \in(\underline{\beta}, 1)$, with $1>\underline{\beta}>0,0<\beta^{\prime}\left(e_{t}\right)<B$ and $B>0$ finite. In the following, $E_{t}$ denotes aggregate environmental quality ${ }^{6}$ at period $t$ and, following John et al. (1995), we consider that $e_{t} \equiv E_{t} / N_{t}$ corresponds to a

\footnotetext{
${ }^{6} E_{t}$ may encompass both environmental conditions (quality of water, air and soils, etc.) and resources availability (fisheries, forestry, etc.). It can be interpreted as an index of the amenity value of the environment. For instance, the Environmental Performance Index (EPI - YCELP) could be a good approximation of this synthetic indicator.
} 
measure of per capita environmental quality in period $t$. We assume that the longevity of an old living at period $t+1$ positively depends on this index of environmental quality faced by the household during his youth.

Preferences of an household born at period $t$ are represented by a log-linear utility function $\left(W_{t}\right)$ defined over consumption when young $c_{t}$ and old $d_{t+1}$, which depends on the longevity $\beta\left(e_{t}\right)$ :

$$
W_{t} \equiv \ln \left(c_{t}\right)+\beta\left(e_{t}\right) \ln \left(d_{t+1} / \epsilon\right)
$$

where $\epsilon>0$ is a scaling parameter, arbitrarily close to zero. This parameter ensures that, for every interior solution, the welfare is increasing in $e_{t}$, given $c_{t}$ and $d_{t+1}$.

At the first period of life, an household born at period $t$ supplies inelastically one unit of labor, remunerated at the competitive real wage $w_{t}$, and pays taxes $\tau_{t} \geqslant 0$. He shares his net income between saving $\sigma_{t}$, through available assets, and consumption $c_{t}$. At the second period of life, saving, remunerated at the real interest factor $r_{t+1},{ }^{7}$ is used to consume the final good. $\beta\left(e_{t}\right) d_{t+1}$ represents all consumption of an household with longevity $\beta\left(e_{t}\right)$ during his second period of life, while $d_{t+1}$ corresponds to the consumption flow of a sub-period when old. In other words, a consumer maximizes his utility function (1) under the two following budget constraints:

$$
\begin{aligned}
\sigma_{t}+c_{t} & =w_{t}-\tau_{t} \\
\beta\left(e_{t}\right) d_{t+1} & =r_{t+1} \sigma_{t}
\end{aligned}
$$

Since the longevity is taken as given by the household, we deduce the following saving function:

$$
\sigma_{t}=\frac{\beta\left(e_{t}\right)}{1+\beta\left(e_{t}\right)}\left(w_{t}-\tau_{t}\right)
$$

We note that saving is an increasing function of longevity.

\footnotetext{
${ }^{7}$ We assume complete depreciation of capital after one period of use. Therefore, $r_{t+1}$ also denotes the real interest rate.
} 


\section{$2.2 \quad$ Firms}

Since each young consumer supplies inelastically one unit of labor, labor used in production at period $t$ is $N_{t}$. Then, the production is given by $y_{t}=f\left(k_{t}\right) N_{t}$, where $k_{t}=K_{t} / N_{t}$ denotes the capital-labor ratio. Assuming a Cobb-Douglas technology, we further have $f\left(k_{t}\right)=k_{t}^{s}$, with $s \in(0,1)$ the capital share in total income. From profit maximization, we get:

$$
\begin{aligned}
r_{t} & =s k_{t}^{s-1} \equiv r\left(k_{t}\right) \\
w_{t} & =(1-s) k_{t}^{s} \equiv w\left(k_{t}\right)
\end{aligned}
$$

\subsection{Environmental quality}

In this economy, we consider that production degrades environmental quality, while public spending, i.e. public environmental abatement, $G_{t} \geq 0$ improves it. Assuming linear relationships, environmental quality follows the motion:

$$
E_{t+1}=(1-m) E_{t}+\gamma G_{t}-\alpha f\left(k_{t}\right) N_{t}
$$

where $\alpha>0$ represents the rate of pollution coming from firms' activities, $\gamma>0$ the efficiency of public abatement, and $m \in(0,1)$, is interpreted as a rate of natural degradation in the quality of the environment. This exogenous rate of degradation represents the speed of return of the environment at a level incompatible with human activities.

\subsection{Public sector}

The aim of the government is to improve environmental quality, using public spending $G_{t}$ to provide pollution abatement and environmental protection programs. To finance these expenditure, as seen above, the government levies taxes $\tau_{t} \geq 0$, or can use debt $B_{t}$. This means that a share of present pollution abatement is financed by future generations, assuming hence that generations who will benefit from the public environmental protection should pay for it. This 
assumption corresponds to a beneficiary-payer principle, enhancing the willingness to implement the environmental policy. Indeed, one of the results of the literature is to show that environmental taxation implies such a welfare loss for present generations that its implementation cannot be wished: one of the generations that would decide it would also bear the heaviest burden. In our model, the living generations should more easily accept public pollution abatement if a share of these activities are financed through public debt, instead of taxes on revenues or consumptions.

The intertemporal budget constraint of the government can be written:

$$
B_{t}=r_{t} B_{t-1}+G_{t}-N_{t} \tau_{t}
$$

with $B_{-1} \geq 0$ given.

\section{Intertemporal equilibrium}

We define the following variables per worker, $b_{t-1} \equiv B_{t-1} / N_{t}$ and $g_{t} \equiv G_{t} / N_{t}$. Equilibrium on the asset market is ensured by:

$$
n\left(k_{t+1}+b_{t}\right)=\sigma_{t}
$$

where the individual saving $\sigma_{t}$ is given by (4). Moreover, the budget constraint of the government (8) can be rewritten:

$$
n b_{t}=r\left(k_{t}\right) b_{t-1}+g_{t}-\tau_{t}
$$

and the law of motion of environmental quality becomes:

$$
n e_{t+1}=(1-m) e_{t}+\gamma g_{t}-\alpha f\left(k_{t}\right)
$$

In order to avoid explosive public expenditure and debt, we assume that debt per worker $b_{t}=b$ and public expenditure per worker $g_{t}=g$ are constant. This also means that debt $B_{t}$ and government spending $G_{t}$ grow both at the 
rate $n-1$. In this case, equation (10) determines the level of the tax faced by each young consumer:

$$
\tau_{t}=\left(r\left(k_{t}\right)-n\right) b+g
$$

Therefore, an intertemporal equilibrium can be defined as follows:

Definition 1 Given $e_{0} \in \mathbb{R}$ and $k_{0} \in \mathbb{R}_{++}$, an intertemporal equilibrium is a sequence $\left(e_{t}, k_{t}\right) \in \mathbb{R} \times \mathbb{R}_{++}, t=0,1, \ldots,+\infty$, such that the following equations are satisfied:

$$
\begin{aligned}
e_{t+1} & =\frac{1}{n}\left[(1-m) e_{t}+\gamma g-\alpha k_{t}^{s}\right] \equiv H\left(e_{t}, k_{t}\right) \\
k_{t+1} & =\frac{\beta\left(e_{t}\right)}{n\left(1+\beta\left(e_{t}\right)\right)}\left[(1-s) k_{t}^{s}-\left(s k_{t}^{s-1}-n\right) b-g\right]-b \equiv G\left(e_{t}, k_{t}\right)
\end{aligned}
$$

We notice that the dynamics are driven by a two-dimensional dynamic system, with two predetermined variables.

\section{Steady states}

A steady state is a solution $(e, k) \in \mathbb{R} \times \mathbb{R}_{++}$that solves:

$$
\begin{aligned}
e & =\frac{\gamma g-\alpha k^{s}}{n-1+m} \equiv \theta(k) \\
\rho(k) \equiv n(k+b) \frac{1+\beta(\theta(k))}{\beta(\theta(k))} & =(1-s) k^{s}-\left(s k^{s-1}-n\right) b-g \equiv \varphi(k)
\end{aligned}
$$

In the limit case without government intervention, i.e. $b=g=0$, we have:

$$
\begin{aligned}
& \rho(k)=n k \frac{1+\beta(\theta(k))}{\beta(\theta(k))} \\
& \varphi(k)=(1-s) k^{s}
\end{aligned}
$$

with $\theta(k)=-\alpha k^{s} /(n-1+m)$. We deduce that there is one steady state $\left(k_{1}, e_{1}\right)$ with $k_{1}=0$ and $e_{1}=0$, and a second one $\left(k_{2}, e_{2}\right)$ such that:

$$
\frac{n}{1-s} k_{2}^{1-s}=\frac{\beta\left(\theta\left(k_{2}\right)\right)}{1+\beta\left(\theta\left(k_{2}\right)\right)}
$$


with $k_{2}>0$ and $e_{2}=-\alpha k_{2}^{s} /(n-1+m)<0$. We notice that since the left-hand side of (19) is increasing in $k_{2}$ and the right-hand side is decreasing, the solution $\left(k_{2}, e_{2}\right)$ is unique. We further have ${ }^{8}$ :

$$
\begin{aligned}
& \varphi^{\prime}\left(k_{1}\right)>\rho^{\prime}\left(k_{1}\right) \\
& \varphi^{\prime}\left(k_{2}\right)<\rho^{\prime}\left(k_{2}\right)
\end{aligned}
$$

Obviously, inequality (20) (inequality (21)) holds in a neighborhood of $k_{1}\left(k_{2}\right)$. Therefore, differentiating $(16), d k / d b>0(d k / d b<0)$ for $k$ sufficiently close to $k_{1}\left(k_{2}\right)$. Moreover, we can show that if

Assumption $1 \beta^{\prime}(e)<\frac{n-1+m}{\gamma n(k+b)} \beta(e)^{2}$ $d k / d g>0(d k / d g<0)$ for $k$ sufficiently close to $k_{1}\left(k_{2}\right)$. Notice that Assumption 1 is satisfied if the longevity is not too sensitive to the environmental index $e$. We deduce that:

Proposition 1 There exists two steady states $\left(k_{1}, e_{1}\right)$ and $\left(k_{2}, e_{2}\right)$, with positive capital-labor ratio $0<k_{1}<k_{2}$ and $e_{1}>e_{2}$, if $b>0$ and/or, under Assumption $1, g>0$, taking into account that $b$ and $g$ are not too large.

\section{Dynamics}

As it is summarized in Proposition 1, two steady states with positive production may coexist. Using a phase diagram, we now qualitatively analyze the dynamics. This allows us to have a picture about convergence. Does it exist a poverty trap for a set of initial conditions $\left(k_{0}, e_{0}\right)$ ? What are the conditions to converge to the steady state with the largest capital-labor ratio? What is the role of the policy parameters $b$ and $g$ ?

${ }^{8}$ Indeed, we have $\varphi^{\prime}(k)=(1-s) s k^{s-1}$ and $\rho^{\prime}(k)=n(1+\beta(e)) / \beta(e)+$ $\left[\beta^{\prime}(e) / \beta(e)^{2}\right] n \alpha s k^{s} /(n-1+m)$. 
Using (13), we immediately see that $e_{t+1} \geqslant e_{t}$ if and only if $e_{t} \leqslant \theta\left(k_{t}\right)$, where $\theta(k)$ is given by (15). Hence, the locus such that $e_{t}$ is stationary describes a negatively slopped curve in the space $\left(k_{t}, e_{t}\right)$. Below this curve, $e_{t}$ is increasing, whereas above it, $e_{t}$ is decreasing (see also Figure 2).

Using (14), we deduce that $k_{t+1} \geqslant k_{t}$ is equivalent to $\Psi\left(e_{t}\right) \leqslant \Phi\left(k_{t}\right)$, with

$$
\begin{aligned}
\Psi\left(e_{t}\right) & \equiv \frac{1+\beta\left(e_{t}\right)}{\beta\left(e_{t}\right)} \\
\Phi\left(k_{t}\right) & \equiv \frac{(1-s) k_{t}^{s}-\left(s k_{t}^{s-1}-n\right) b-g}{n\left(k_{t}+b\right)}
\end{aligned}
$$

Since $\beta\left(e_{t}\right)$ is increasing, $\Psi\left(e_{t}\right)$ is decreasing, with $\Psi\left(e_{t}\right)>2$. However, we observe that there exists a solution to the equation $\Psi\left(e_{t}\right)=\Phi\left(k_{t}\right)$ if $b=g=0$, meaning that this still holds if $b>0$ and $g>0$ are not too large. In this case, $\Psi\left(e_{t}\right) \leqslant \Phi\left(k_{t}\right)$ is equivalent to $e_{t} \geqslant \Psi^{-1} \circ \Phi\left(k_{t}\right) \equiv \Gamma\left(k_{t}\right)$.

Using (23), we get:

$$
\Phi^{\prime}(k)=\frac{g-n b-h(k)}{n(k+b)^{2}}
$$

with

$$
h(k) \equiv(1-s)^{2} k^{s}-b s(3-2 s) k^{s-1}-s(1-s) b^{2} k^{s-2}
$$

Since $h^{\prime}(k)>0, h(0)=-\infty$ and $h(+\infty)=+\infty$, there exists a unique $k^{*}$ such that $\Phi^{\prime}(k)>0\left(\Phi^{\prime}(k)<0\right)$ for $k<k^{*}\left(k>k^{*}\right)$. This means that $\Phi(k)$ is inverted U-shaped. Since $\Psi(e)$ is decreasing, we deduce that the locus $e_{t}=\Gamma\left(k_{t}\right)$ is $\mathrm{U}$-shaped in the space $\left(k_{t}, e_{t}\right)$. Moreover, above this curve, $k_{t}$ is increasing, while below it, $k_{t}$ is decreasing (see Fig. 2).

Using all these results, the dynamics are determined as in Figure 2. Obviously the two points, where the curves $\theta\left(k_{t}\right)$ and $\Gamma\left(k_{t}\right)$ cross, correspond to the two steady states $\left(k_{1}, e_{1}\right)$ and $\left(k_{2}, e_{2}\right)$.

This analysis allows to have a global picture of the dynamics. Recalling that both $k_{t}$ and $e_{t}$ are predetermined variables, the steady state $\left(k_{2}, e_{2}\right)$ is stable, 


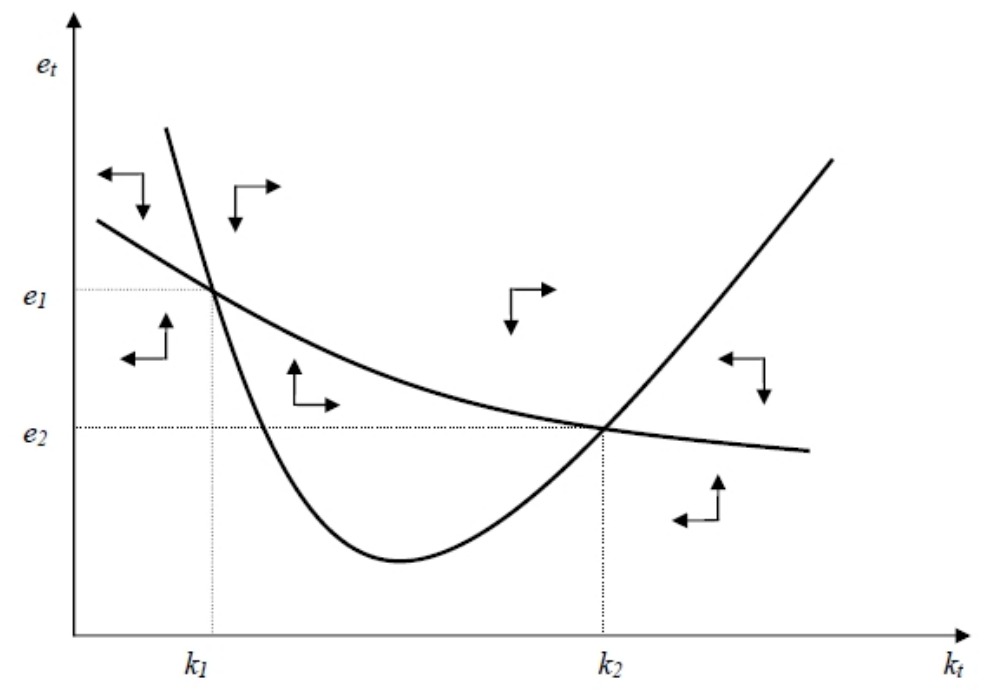

Figure 2: Phase diagram.

while the other one $\left(k_{1}, e_{1}\right)$ is an unstable saddle. This means that starting with initial conditions, such that the capital-labor ratio is not too low, the economy converges to the steady state with the higher capital stock. In contrast, the existence of the saddle with $k_{1}>0$ implies that there is a poverty trap. Indeed, if the initial capital stock is too small, capital decreases and the economy can never reach the steady state $\left(k_{2}, e_{2}\right)$. In opposition to many papers (e.g. John and Pecchenino, 1994; John et al., 1995; Mariani et al., 2010), we show that a conflict between environmental quality and capital accumulation may exist. This is because we do not consider private engagement in pollution abatement, pollution is hence a pure externality for households. This conflict seems quite realistic as it squares with the increasing part of the Environmental Kuznets Curves, which corresponds to many developing countries (see Figures ${ }^{9} 3$ and 4) or to some global pollutants, like $\mathrm{CO} 2$ emissions.

\footnotetext{
${ }^{9}$ For details, see Figure 1, page 5.
} 


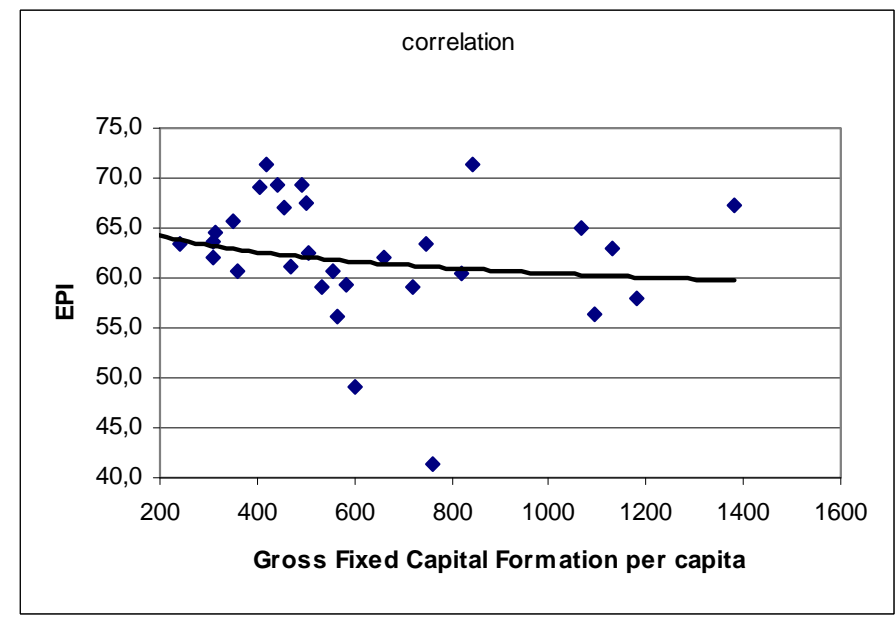

Figure 3: Environmental quality and capital fomation (2004).

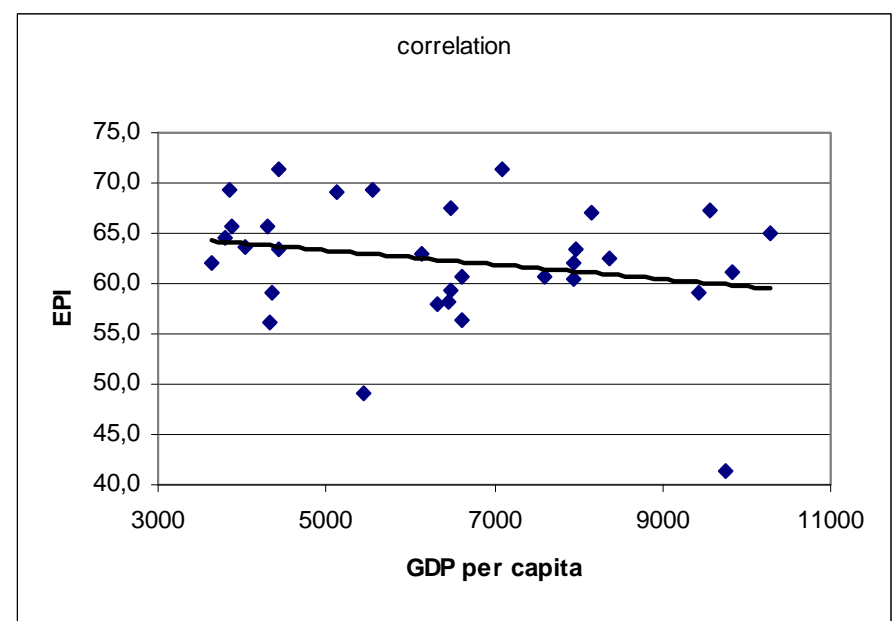

Figure 4: Environmental quality and GDP (2004). 
As seen in Section 4, increasing $b$ and/or $g$ raises $k_{1}$, taking into account that both $b$ and $g$ are not too large. Therefore, this widens the range of initial conditions $\left(k_{0}, e_{0}\right)$ such that the economy is relegated into the poverty trap.

To understand the occurrence of the poverty trap, assume first that there is no debt $(b=0)$, i.e. public expenditure is financed by taxation $\left(\tau_{t}=g>0\right)$. In this case, if the capital stock is too low, the wage is quite small, implying that the disposable income is not large enough to sustain capital accumulation. However, this may be mitigated by a larger longevity, which improves savings. Therefore, a higher initial environmental quality makes the emergence of the trap harder.

A closely related intuition explains why debt promotes the existence of the trap. The main effect comes from the fact that in the presence of a positive debt, a share of saving is devoted to buy unproductive assets $(b)$. Therefore, if the initial capital stock is again too low, the disposable income of young households is not large enough to sustain the growth of the capital stock.

\section{Comparative statics}

We analyze comparative statics to clearly see the effects of government intervention, through $b$ and $g$, on the levels of capital and environment per worker at the two steady states. Why is it relevant to study comparative statics at the two steady states? On one hand, $\left(k_{2}, e_{2}\right)$ is stable and an economy converges to this equilibrium in the long run as long as its initial conditions are not too low. On the other hand, $\left(k_{1}, e_{1}\right)$ marks, in a sense, the boundary of the trap.

The two-dimension system that defines the steady state solutions writes (see equations (13) and (14)):

$$
\begin{gathered}
(n-1+m) e=\gamma g-\alpha k^{s} \\
n(k+b) \frac{1}{\beta(e)}=(1-s) k^{s}-s k^{s-1} b-g-n k
\end{gathered}
$$


Total differentiation of equations (26) and (27) yields:

$$
A\left[\begin{array}{l}
d k \\
d e
\end{array}\right]=\left[\begin{array}{cc}
0 & \gamma \\
-\beta(e) s k^{s-1}-n & -\beta(e)
\end{array}\right]\left[\begin{array}{l}
d b \\
d g
\end{array}\right]
$$

with

$$
A=\left[\begin{array}{cc}
\xi & \chi \\
\kappa & \zeta
\end{array}\right]=\left[\begin{array}{cc}
\alpha s k^{s-1} & n-1+m \\
n(1+\beta(e))-s \beta(e)(1-s) k^{s-2}[k+b] & -\frac{\beta^{\prime}(e)}{\beta(e)} n(k+b)
\end{array}\right]
$$

Lemma 1 The determinant of $A$ is positive (negative) when it is evaluated at the steady state with low capital $\left(k_{1}, e_{1}\right)$ (high capital $\left(k_{2}, e_{2}\right)$ ).

Proof. See the Appendix A.

System (28) writes:

$$
\left[\begin{array}{c}
d k \\
d e
\end{array}\right]=\frac{1}{\operatorname{det} A}\left[\begin{array}{cc}
\chi\left[\beta(e) s k^{s-1}+n\right] & \zeta \gamma+\chi \beta(e) \\
-\xi\left[\beta(e) s k^{s-1}+n\right] & -\kappa \gamma-\beta(e) \xi
\end{array}\right]\left[\begin{array}{c}
d b \\
d g
\end{array}\right]
$$

We further assume:

Assumption $2 \gamma$ is low enough, i.e. satisfies the following inequality, evaluated at the two steady states $\left(k_{1}, e_{1}\right)$ and $\left(k_{2}, e_{2}\right)$ :

$$
\gamma\left[n(1+\beta(e))-s \beta(e)(1-s) k^{s-2}(k+b)\right]+\beta(e)(n-1+m)>0
$$

We note that a low $\gamma$ is also in accordance with Assumption 1. Assumption 2 ensures that $\kappa \gamma+\beta(e) \xi$ is strictly positive, while Assumption 1 imposes $\zeta \gamma+$ $\chi \beta(e)>0$.

We deduce the total consequences of variations of public debt or of public abatement, as summarized in the following proposition and in Table 1. 


\begin{tabular}{|c|c|c|c|}
\hline \multicolumn{2}{|c|}{} & $d b$ & $d g$ \\
\hline \hline Low capital steady state & $d k_{1}$ & + & + \\
\cline { 2 - 4 } & $d e_{1}$ & - & - \\
\hline \hline High capital steady state & $d k_{2}$ & - & - \\
\cline { 2 - 4 } & $d e_{2}$ & + & + \\
\hline
\end{tabular}

Table 1: Final effect on equilibrium $(\mathrm{k}, \mathrm{e})$

Proposition 2 Under Assumptions 1 and 2, an increase in debt per capita $b$ and/or an increase in public abatement per capita $g$ will increase (decrease) the capital stock and increase (decrease) the environmental quality at the steady state with low capital $\left(k_{1}, e_{1}\right)$ (high capital $\left(k_{2}, e_{2}\right)$ ).

In other words, a higher debt and/or public abatement reduces capital but improves environmental quality at the stable steady state. Opposite effects are observed for the unstable saddle steady state. This means that the range of initial conditions $\left(k_{0}, e_{0}\right)$, such that the economy is relegated to a trap, becomes larger.

The mechanisms underlying these results are quite intuitive. Let us focus on the steady state $\left(k_{2}, e_{2}\right)$ as it is the stable one. Any increase of the public debt $(d b>0)$ will induce a crowding-out effect on capital accumulation, private saving will support the financing of the public debt instead of the private investment. Doing so, the capital stock decreases and production of goods decreases too. This turns to a fall in pollutant emissions which enhances environmental quality. On the other hand, any increase of public engagement $(d g>0)$, ceteris paribus, will require a higher tax rate, that will also slow down the economic activity.

Still focusing on the stable steady state $\left(k_{2}, e_{2}\right)$, we study whether the government intervention, summarized by the two instruments $b$ and $g$, can improve both capital accumulation and environmental quality. In order to conciliate higher environmental quality with capital accumulation evolution, we show 
that government should decrease debt and increase environmental protection programs (as in the debt-for-nature swaps solution).

Using the differentiation of the steady state with respect to $b$ and $g$, at the equilibrium $\left(k_{2}, e_{2}\right)$ where $\operatorname{det} A<0, d k>0$ and $\operatorname{de}>0$ are equivalent to:

$$
d b<G_{1} d g \text { and } d b>G_{2} d g
$$

with

$$
\begin{aligned}
G_{1} & =-\frac{\zeta \gamma+\chi \beta(e)}{\chi\left[\beta(e) s k^{s-1}+n\right]} \\
G_{2} & =-\frac{\kappa \gamma+\beta(e) \xi}{\xi\left[\beta(e) s k^{s-1}+n\right]}
\end{aligned}
$$

We may easily see that because $\operatorname{det} A<0$, we have $G_{2}<G_{1}<0$. This allows us to deduce the following proposition:

Proposition 3 Suppose that Assumptions 1 and 2 are satisfied. At the stable steady state $\left(k_{2}, e_{2}\right)$, both capital and environmental quality increase $(d k>0$, de $>0)$ if and only if government spending increases $(d g>0)$ and debt reduces $(d b<0)$, according to:

$$
G_{2} d g<d b<G_{1} d g
$$

The main intuition of this result is the following. A higher public spending improves environmental quality through public abatement. It also reduces capital accumulation because of a higher level of taxation. To ensure a higher level of capital, a lower debt is required to reduce its crowding out effect and promote capital accumulation.

The welfare analysis shows that households' welfare evaluated at a steady state is increasing in the environmental quality only (see the Appendix B). This provides an adding argument in favor of the policy investigated in Proposition 3.

Regarding the set of 32 developing countries, a closer look to the data, with help of results of Proposition 3, shows that Uruguay, Brazil, Botswana, Turkey, 
Panama, Malaysia, Gabon, Venezuela, Lebanon and Mexico would benefit from environmental policies based on debt-for-nature swaps mechanism. Conversely, Ukraine, Philippines, Paraguay, Egypt, Sri Lanka, Syria, Morocco, Macedonia and El Salvador should probably postpone environmental policies in the short term, and concentrate on economic growth. Otherwise, these economies may converge toward a poverty trap.

\section{Conclusion}

Among several countries, non explosive public debt is a major constraint. Nevertheless, the growing concerns about the environmental degradation (biodiversity losses, climate change...) lead many governments to fight against pollution and hence, to increase environmental spending. In many countries, the pollution mitigation induces the adoption of environmental taxes bearing on households, alongside with the increase of the individual environmental engagements.

In this paper, public abatement is not only financed by taxation, but also by debt emission. We show that, under a stabilizing debt constraint, the environmental public policy may lead the economy to a poverty-environmental trap. Indeed, with a higher level of public debt, the stabilization of the latter reduces households' share of income devoted to productive saving. This result is reinforced by a larger public spending.

This allows us to recommend that policy-makers should carefully evaluate the level of public debt before increasing their environmental engagement. Finally, for developing countries that are converging towards a higher capital stock equilibrium, debt-for-nature swaps could be a win-win solution. 


\section{References}

Bovenberg, A. L., Heijdra, B.J. (1998), "Environmental tax policy and intergenerational distribution", Journal of Public Economics 67, 1-24.

Cassimon, D., Prowse, M., Essers, D. (2009), "The pitfalls and potential of debt-for-nature swaps: A US-Indonesian case study", WORKING PAPER / 2009.07, Institute of Development Policy and Management, IOB, University of Antwerp.

Diamond, P. (1965), "National debt in a neoclassical growth model", American Economic Review 55, 1126-1150.

Fodha, M., Seegmuller, T. (2011), "A note on environmental policy and public debt stabilization", Macroeconomic Dynamics, in press.

Hansen, S. (1989), "Debt for nature swaps: Overview and discussion of key issues", Ecological Economics 1(1), 77-93.

Heijdra, B.J., Kooiman, J.P., Ligthart, J.E. (2006), "Environmental quality, the macroeconomy, and intergenerational distribution", Resource and Energy Economics 28, 74-104.

Howarth, R., Norgaard, R. (1992), "Environmental valuation under sustainable development", American Economic Review, 82, 473-477.

Jha, R., Schatan, C. (2001), "Debt for nature: A swap whose time has gone?", Working Paper, ECLAC, Santiago de Chile.

John, A., Pecchenino, R. (1994), "An overlapping generations model of growth and the environment", Economic Journal 104, 1393-1410.

John, A., Pecchenino, R., Schimmelpfennig, D., Schreft, S. (1995), "Short-lived Agents and the Long-lived Environment", Journal of Public Economics 58, 127141. 
Jouvet, P.A., Pestieau, P., Ponthière, G. (2010) "Longevity and Environmental Quality in an OLG model", Journal of Economics.

Jouvet, P.A., Michel, P., Vidal, J.P. (2000), "Intergenerational altruism and the environment", Scandinavian Journal of Economics.

Kampa, M., Castanas, E. (2008), "Human health effects of air pollution", Environmental Pollution 151 (2), 362-367.

Mariani, F., Perez Barahona, A., Raffin, N. (2010), "Life expectancy and the environment", Journal of Economic Dynamics \& Control, doi:10.1016/j.jedc.2009.11.007.

Moye, M. (2003), Bilateral debt-for-environment swaps by creditor. WWF Center for Conservation Finance.

Neuberg, M., Rabczenko, D., Moshammer, H. (2007), "Extended effects of air pollution on cardiopulmonary mortality in Vienna", Atmospheric Environment $41(38), 8549-8556$.

OECD (2008), Environmental Outlook to 2030. Organization for Economic Cooperation and Development, Paris.

Pautrel, X. (2008), "Reconsidering the impact of pollution on long-run growth when pollution influences health and agents have a finite-lifetime", Environmental and Resource Economics, 40(1), 37-52.

Ruiz, M. (2007), Debt swaps for development: Creative solution or smoke screen?, EURODAD, Brussels.

Stern, N. (2007), Stern Review on the Economics of Climate Change, Cambride University Press.

Sheikh, P.A. (2008), Debt-for-nature initiatives and the Tropical Forest Conservation Act: Status and implementation. CRS Report for Congress.

Varvarigos, D. (2010), "Environmental degradation, longevity, and the dynamics of economic development", Environmental and Resource Economics. 
World Bank, (2010), World Development Indicators. [data available on-line at http://data.worldbank.org/data-catalog/world-development-indicators] Yale Center for Environmental Law and Policy, (2010), Environmental Performance Index. [data available on-line at http://epi.yale.edu]

\section{Appendix}

\section{Appendix A (Sign of the determinant of matrix A)}

Remember that the two steady states $\left(k_{1}, e_{1}\right)$ and $\left(k_{2}, e_{2}\right)$ are such that:

$$
\begin{aligned}
& \varphi^{\prime}\left(k_{1}\right)>\rho^{\prime}\left(k_{1}\right) \\
& \varphi^{\prime}\left(k_{2}\right)<\rho^{\prime}\left(k_{2}\right)
\end{aligned}
$$

where $\varphi(k)$ and $\rho(k)$ are defined in equation (16) and:

$$
\begin{aligned}
\rho^{\prime}(k) & =n \frac{1+\beta(e)}{\beta(e)}+n(k+b) \frac{\beta^{\prime}(e)}{\beta(e)^{2}} \frac{\alpha s k^{s-1}}{n-1+m} \\
\varphi^{\prime}(k) & =(1-s) s k^{s-2}(k+b)
\end{aligned}
$$

Using the definition of the matrix $A$, we can compute:

$$
\begin{aligned}
\operatorname{det} A= & \xi \zeta-\chi \kappa \\
= & \beta(e)(n-1+m)\left[(1-s) s k^{s-2}(k+b)-n \frac{1+\beta(e)}{\beta(e)}\right. \\
& \left.-n(k+b) \frac{\beta^{\prime}(e)}{\beta(e)^{2}} \frac{\alpha s k^{s-1}}{n-1+m}\right]
\end{aligned}
$$

One may easily see that this expression is equivalent to:

$$
\operatorname{det} A=\beta(e)(n-1+m)\left(\varphi^{\prime}(k)-\rho^{\prime}(k)\right)
$$

We deduce that $\operatorname{det} A>0$ when the matrix $A$ is evaluated at the steady state $\left(k_{1}, e_{1}\right)$, while $\operatorname{det} A<0$ when the matrix $A$ is evaluated at the steady state $\left(k_{2}, e_{2}\right)$. 


\section{Appendix B (Welfare analysis at the steady state)}

Any decentralized solution is such that $d_{t+1}=r_{t+1} c_{t}$.

The budget constraints can be rewritten:

$$
c_{t}+\frac{\beta\left(e_{t}\right) d_{t+1}}{r_{t+1}}=w_{t}-\tau_{t}
$$

We deduce that $d d_{t+1} / d c_{t}=-r_{t+1} / \beta\left(e_{t}\right)$.

Welfare at the steady state is given by $W \equiv \ln c+\beta(e) \ln (d / \epsilon)$. Total differentiation of this welfare gives:

$$
d W=\frac{d c}{c}+\beta(e) \frac{d d}{d}+\beta^{\prime}(e)(\ln d-\ln \epsilon) d e
$$

Using $d_{t+1}=r_{t+1} c_{t}$ and $d d_{t+1} / d c_{t}=-r_{t+1} / \beta\left(e_{t}\right)$ evaluated at the steady state, we obtain:

$$
d W=\beta^{\prime}(e)(\ln d-\ln \epsilon) d e
$$

Therefore, since $\epsilon$ is arbitrarily small, $d W / d e>0$. Evaluated at a steady state, the welfare is only increasing in environmental quality $e$. 